\title{
Penentuan Breakdown Voltage Karburasi Plasma dan Pemanfaatannya untuk Meningkatkan Kekerasan Stainless Steel 316L \\ Vanny Alpanesa Butar Butar ${ }^{a^{*}}$, Tjipto Sujitno ${ }^{b}$, Boni P. Lapanporo ${ }^{a}$
}

\author{
aProdi Fisika, FMIPA Universitas Tanjungpura, b PSTA BATAN Yogyakarta \\ *Email : Vannyalpanessa@gmail.com
}

\begin{abstract}
Abstrak
Penelitian bertujuan menentukan breakdown voltage karburasi plasma dan pemanfaatannya untuk meningkatkan kekerasan stainless steel 316L. Proses penentuan breakdown voltage karburasi plasma dilakukan dengan menggunakan gas $\mathrm{CH}_{4}$ dengan variasi tekanan $1 ; 1,2 ; 1,4 ; 1,6 ; 1,8 ; 2$ mbar. Selain itu juga dilakukan proses surface treatment menggunakan gas $\mathrm{CH}_{4}$ dengan teknik karburasi plasma pada stainless steel 316L untuk meningkatkan kekerasan dengan variasi tekanan 1,2; 1,4; 1,6; 1,8 mbar. Breakdown voltage yang diperoleh dari perlakuan variasi tekanan berturut-turut sebesar 512 ; 540 ; 572,3; 602; 654,3; dan 655,7 volt, sedangkan nilai arus yang diperoleh berturut-turut 256; 457; 547; 708,3; 947,7; 986,7 mA. Hasil uji kekerasan menunjukkan nilai kekerasan optimum terjadi pada variasi tekanan 1,6 mbar dengan nilai kekerasan meningkat dari 109,4 VHN menjadi 228,6 VHN, atau meningkat sebanyak 108,88\%.
\end{abstract}

Kata Kunci : Karburasi plasma, Stainless Steel 316L, surface treatment, breakdown voltage, uji kekerasan.

\section{Latar Belakang}

Perkembangan teknologi baik industri maupun otomotif yang semakin meningkat seharusnya diikuti dengan inovasi komponenkomponen permesinan seperti logam. Salah satu jenis logam adalah baja tahan karat yang juga dikenal sebagai stainless steel. Bahan ini memiliki sifat kekuatan, keuletan, ketangguhan, dan ketahanan korosi yang sangat baik. Karena keunggulannya ini, baja tahan karat banyak digunakan di bidang teknik, misalnya untuk komponen permesinan, pembuatan turbin, mesin jet, pesawat terbang, bejana tekan, pembuatan peralatan perkakas, dan lain-lain[1]. Selain itu baja juga banyak digunakan di bidang biomedis dan petrokimia, teknik kimia, dan masih banyak lagi [2]. Salah satu jenis stainless steel adalah SS 316L. Di bidang kedokteran SS 316L dimanfaatkan untuk memperbaiki atau menggantikan fungsi suatu sistem ototkerangka tubuh manusia yang rusak [3]. SS 316L banyak digunakan untuk material implan karena harganya murah. Akan tetapi berdasarkan kajian medis, sebagian besar pencangkokkan ortopedik mengalami kegagalan sebesar 90\% diakibatkan korosi karena interaksi material dengan cairan tubuh manusia dan terjadi keausan karena menahan beban gesekan dalam tulang sendi [4]. SS 316L mempunyai nilai ketahanan aus dan gesek yang kurang baik. Untuk meningkatkan ketahanan aus, kekerasan pada SS 316L harus ditingkatkan, salah satunya adalah dengan pelapisan permukaan yang diharapkan dapat memperbaiki sifat-sifat mekanik dari baja tersebut [5].
Untuk memperoleh kualitas yang baik, diperlukan suatu teknologi yang dapat mengubah dan memperbaiki sifat mekanik permukaan logam seperti baja. Salah satunya adalah dengan surface treatment, yaitu suatu perlakuan untuk meningkatkan kualitas/mutu suatu material sesuai yang diinginkan. Dengan perlakuan pada permukaan, yang mengalami perubahan sifat hanya pada permukaannya saja, sedangkan pada bagian dalam logam sifatnya tidak berubah [6]. Cara untuk meningkatkan kualitas permukaan dapat dilakukan dengan teknik plasma lucutan pijar. Teknik plasma lucutan pijar merupakan teknik modern yang paling sederhana dan mudah dalam pengoperasiannya [7].

Penelitian terkait surface treatment dengan metode plasma untuk peningkatan sifat kekerasan material, telah dilakukan oleh Rhajendra Ekaputra pada tahun 2016. Dalam penelitiannya, digunakan gas $\mathrm{CH}_{4}$ dan helium dengan suhu konstan $400^{\circ} \mathrm{C}$, dengan variasi waktu 2, 3, 4, dan 5 jam, sedangkan tekanan divariasikan untuk nilai 2,2; 2,5; 2,8; dan 3,1 mbar. Hasil pengujian menunjukkan bahwa proses plasma carburizing dapat meningkatkan kekerasan material baja poros dari 115,51 VHN menjadi 319,38 VHN atau mengalami kenaikan $179,49 \%$ pada tekanan 2,8 mbar dan waktu 4 jam. Sedangkan dari uji aus diperoleh nilai optimum pada parameter yang sama, meningkat dari laju keausan awal 2,1 x $10^{-5} \mathrm{~mm}^{2} / \mathrm{kg}$ menjadi $2,81 \times 10^{-4} \mathrm{~mm}^{2} / \mathrm{kg}$ atau mengalami penurunan 99,25\%. Hasil dari uji korosi menunjukkan nilai laju korosi mengalami 
peningkatan dari 19,796 mils per year (mpy) menjadi 24,266 mpy pada parameter optimum.

Berdasarkan pemaparan uraian di atas, maka dalam penelitian ini dilakukan penentuan breakdown voltage karburasi plasma menggunakan gas $\mathrm{CH} 4$ dengan tekanan divariasikan dan variabel yang diamati meliputi besar tegangan yang dibutuhkan untuk membangkitkan plasma di dalam tabung (breakdown voltage) dan arus yang dihasilkan. Selanjutnya dilakukan peningkatan kekerasan bahan dengan menggunakan karburasi plasma pada permukaan baja tahan karat SS 316L dengan variasi tekanan Pembentukan lapisan tipis dilakukan menggunakan gas $\mathrm{CH} 4$ dengan memanfaatkan unsur karbon. Kandungan karbon dalam baja dapat meningkatkan kekerasan pada permukaan benda kerja dan diharapkan akan membentuk senyawa besi karbida (Fe-C). Efek dari karburasi plasma terhadap benda kerja SS 316L selanjutnya diuji perubahan kekerasannya dengan menggunakan microhardness tester MMT-X7.

\section{Metodologi}

\subsection{Waktu dan Tempat Penelitian}

Penelitian dilaksanakan pada bulan Maret hingga September 2019 di Laboratorium Pusat Sains dan Teknologi Akselerator Badan Tenaga Nuklir Nasional (PSTA BATAN) Yogyakarta

\subsection{Alat dan Bahan}

Alat yang digunakan dalam penelitian adalah sebagai berikut: mesin plasma lucutan pijar DC, alat pencuci ultrasonik, alat uji kekerasan, dan mesin penghalus. Sedangkan bahan yang digunakan pada penelitian adalah sebagai berikut: material SS 316L, gas metana $\left(\mathrm{CH}_{4}\right)$, kertas abrasive, alkohol, cairan resin dan pengeras resin, plastik klip, kertas tisu, autosol, dan deterjen.

\subsection{Prosedur Penelitian}

Prosedur pertama yang dilakukan yaitu pengambilan data Breakdown Voltage. Langkah awal yang perlu dilakukan dalam penelitian ini adalah melakukan pengecekan kondisi mesin plasma dalam keadaan baik untuk digunakan. Apabila kondisi alat dalam keadaan baik, maka dilakukan proses pemvakuman tabung reaktor hingga tingkat kevakuman mencapai orde $10^{-2}$ mbar. Ketika telah mencapai orde $10^{-2}$ mbar gas metana $\left(\mathrm{CH}_{4}\right)$ dimasukkan ke dalam tabung. Selanjutnya kontrol tegangan diatur hingga muncul discharge yang terlihat di jendela tabung. Pada penelitian ini nilai tekanan divariasikan, yaitu 1,0; 1,2, 1,4, 1,6, 1,8 dan 2,0 sebanyak 3 kali pengukuran. Diagram alur uji surface treatment dapat dilihat pada Gambar 1.

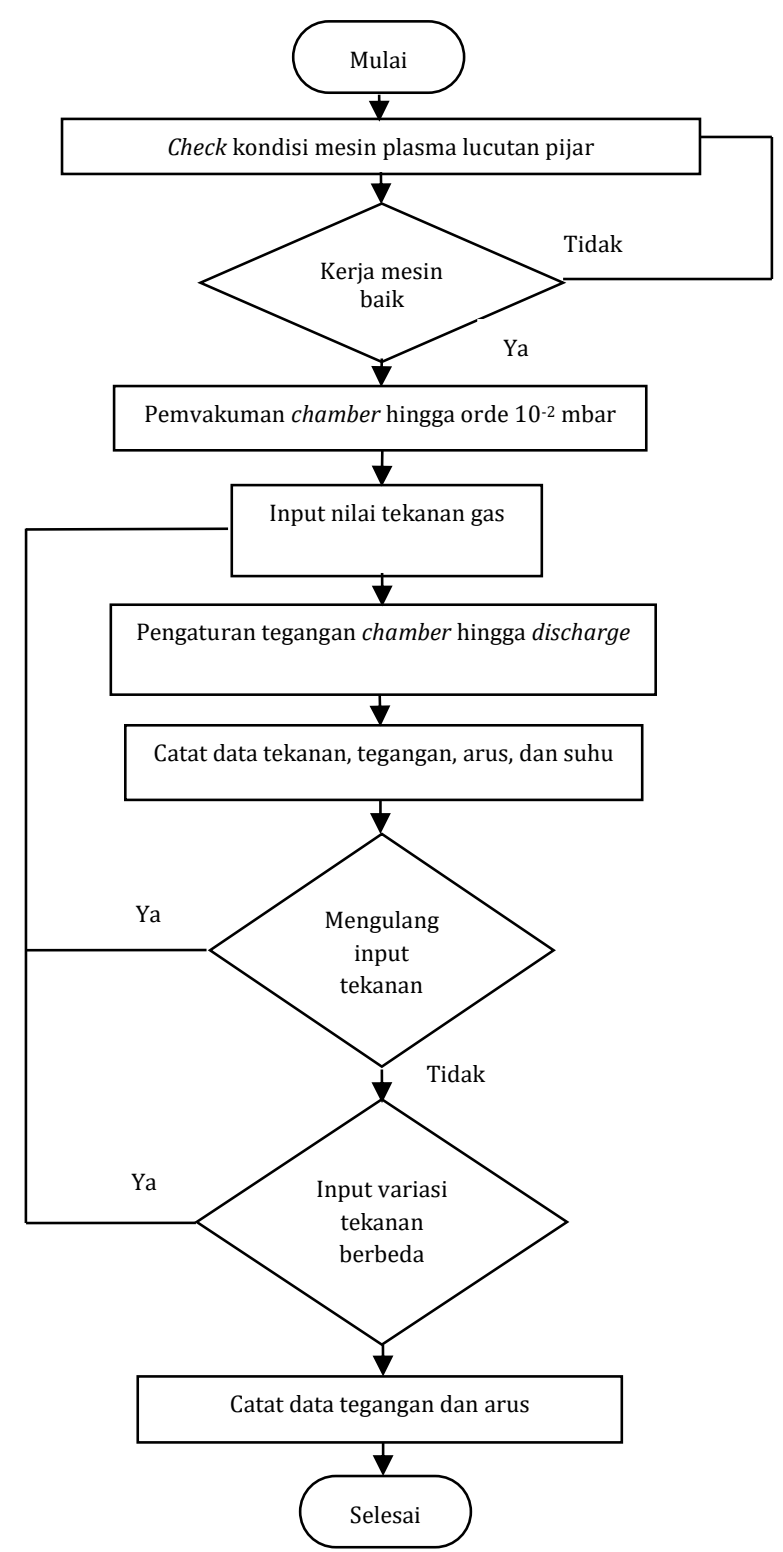

Gambar 1. Diagram alur breakdown voltage

Prosedur kedua yang dilakukan yaitu pengambilan data Surface Treatment. Hal pertama yang dilakukan adalah memastikan bahwa mesin plasma dalam keadaan baik untuk digunakan. Jika kondisi alat dalam keadaan baik, material yang ingin diberi perlakuan (SS 316L) dimasukkan pada meja sampel yang ada dalam tabung reaktor. Proses pemvakuman tabung reaktor dilakukan hingga tingkat pemvakuman mencapai orde $10^{-2}$ mbar. Ketika telah mencapai orde $10^{-2}$ mbar, gas metana $\left(\mathrm{CH}_{4}\right)$ dialirkan ke dalam tabung, lalu tekanan divariasikan sesuai keinginan. Tekanan gas divariasikan dengan cara mengatur kecepatan aliran gas. Kontrol tegangan diatur hingga terjadi discharge dan nyala normal di dalam tabung plasma. Proses perlakuan permukaan dilakukan selama 4 jam pada suhu $40^{\circ} \mathrm{C}$. 
Diagram alur uji surface treatment dapat dilihat pada Gambar 2.

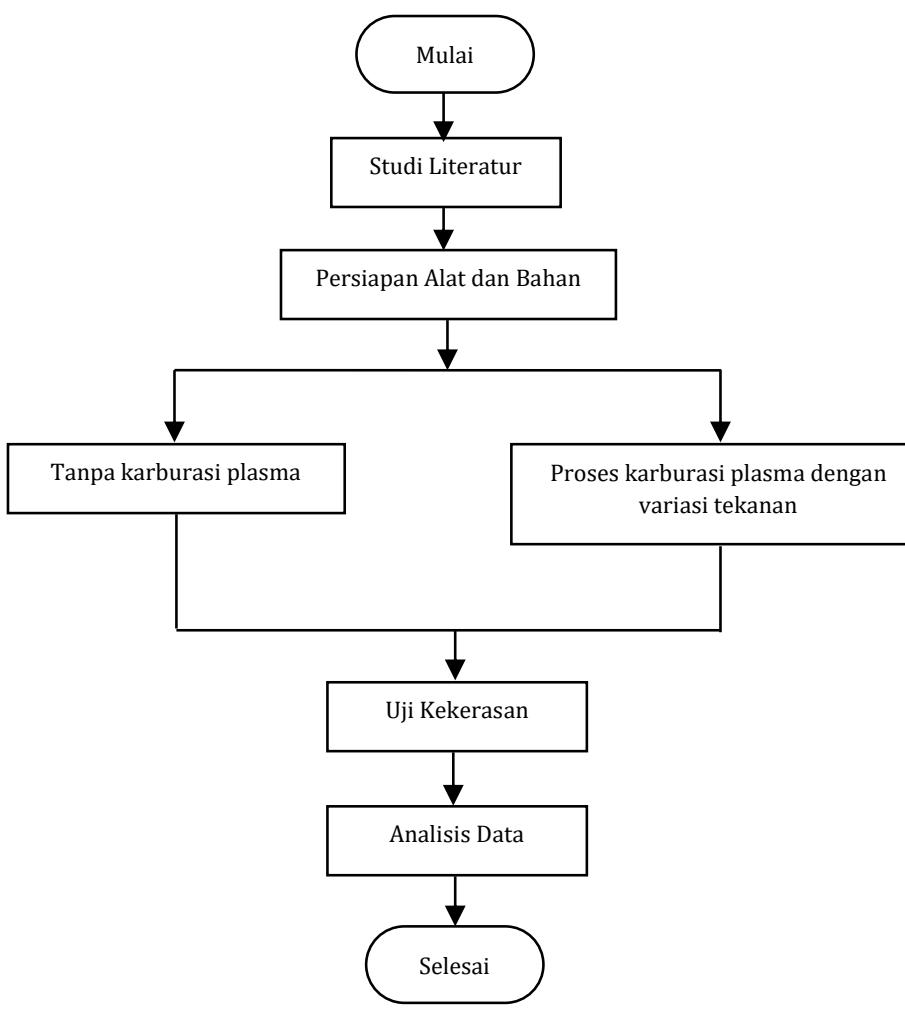

Gambar 2. Diagram alur surface treatment

\subsection{Cara Kerja}

\section{Persiapan Bahan}

Bahan material SS 316L dipotong berbentuk lingkaran. Kemudian permukaan material dihaluskan dengan kertas abrasive. Setelah selesai diamplas, sisa-sisa kotoran yang menempel dibersihkan dengan deterjen, alkohol, dan air menggunakan mesin pencuci ultrasonik.

\section{Proses uji kekerasan}

Uji kekerasan dilakukan di Laboratorium Fisika Partikel PSTA-BATAN. Dalam proses pengambilan data uji kekerasan, tahap pertama dengan melakukan kegiatan pengukuran kekerasan material sebelum diberi perlakuan. Tahap kedua melakukan proses karburasi plasma dengan cara memvariasikan tekanan. Setelah proses perlakuan permukaan selesai, pengukuran kekerasan material kembali dilakukan kemudian dibandingkan dengan kondisi sebelum diberi perlakuan. Uji kekerasan dilakukan dengan menggunakan alat microhardness dengan indentor (penidik). Beban yang digunakan $10 \mathrm{~g}$ dengan waktu indentasi 10 detik serta dilakukan pada 5 titik yang berbeda pada permukaan SS tipe 316L.

\section{Analisis Data}

Data arus dan breakdown voltage yang diperoleh dari penentuan breakdown voltage ditampilkan dalam bentuk grafik dan tabel dan dilihat hubungannya. Selanjutnya, dilakukan perhitungan persentase (\%) kenaikan tingkat kekerasan pada data hasil pengujian dengan persamaan (1) sebagai berikut:

$$
\%=\frac{\text { kekerasan akhir-kekerasan awal }}{\text { kekerasan awal }} \times 100 \%
$$

\section{Hasil dan Pembahasan}

\subsection{Penentuan Breakdown Voltage}

Breakdown voltage adalah tegangan minimum dari elektroda agar dapat membentuk plasma. Pada penelitian ini dilakukan percobaan penentuan breakdown voltage untuk gas metana $\left(\mathrm{CH}_{4}\right)$ dengan variasi tekanan gas sehingga diperoleh data seperti Tabel 1.

Tabel 1. Nilai breakdown voltage dan arus dengan variasi tekanan

\begin{tabular}{c|cccc|cccc}
\hline \multirow{2}{*}{$\begin{array}{c}\text { Tekanan } \\
\text { (mbar) }\end{array}$} & \multicolumn{9}{|c|}{ Tegangan (volt) } & \multicolumn{4}{c}{ Arus (mA) } \\
\cline { 2 - 9 } & 1 & 2 & 3 & $\begin{array}{c}\text { Rata- } \\
\text { rata }\end{array}$ & 1 & 2 & 3 & $\begin{array}{c}\text { Rata- } \\
\text { rata }\end{array}$ \\
\hline 1 & 537 & 511 & 488 & 512 & 259 & 237 & 272 & 256 \\
1.2 & 543 & 532 & 545 & 540 & 446 & 463 & 462 & 457 \\
1.4 & 581 & 596 & 540 & 572,3 & 565 & 538 & 538 & 547 \\
1.6 & 619 & 601 & 586 & 602 & 708 & 706 & 711 & 708,3 \\
1.8 & 653 & 651 & 659 & 654,3 & 944 & 935 & 964 & 947,7 \\
2 & 669 & 659 & 639 & 655,7 & 942 & 1020 & 998 & 986,7 \\
\hline
\end{tabular}

Pengamatan ini menunjukkan bahwa makin tinggi tekanan (makin rendah kevakuman) maupun makin tinggi tegangan catu daya maka akan dihasilkan intensitas plasma yang makin besar. Pada tekanan berturut-turut $1 ; 1,2 ; 1,4$; 1,6; 1,8; 2 mbar, plasma terbentuk ketika tegangan $512 ; 540 ; 572,3 ; 602 ; 654,3 ; 655,7$ volt dan arus plasma diperoleh sebesar 256; 457; 547; 708,3; 947,7; 986,7 mA. Semakin tinggi tekanan, maka semakin besar nilai breakdown voltage yang dibutuhkan agar plasma terbentuk. Grafik hubungan tekanan dan tegangan dapat dilihat pada Gambar 3.

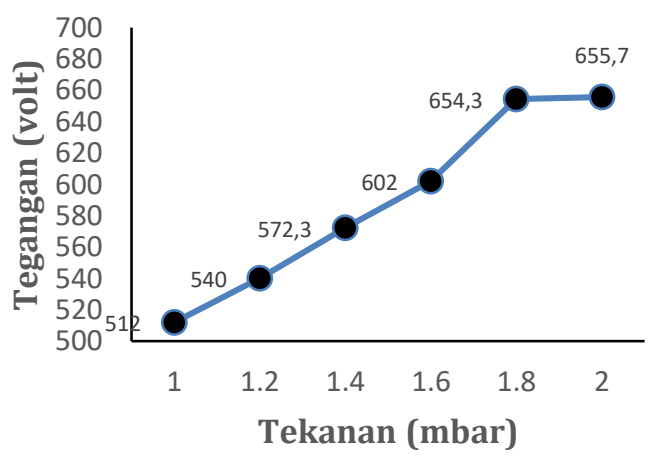

Gambar 3. Grafik hubungan tekanan dan tegangan 
Pada Gambar 3 dapat dilihat bahwa nilai breakdown voltage dipengaruhi oleh besar tekanan gas yang dialirkan. Bertambahnya nilai tekanan gas yang diberikan pada mesin plasma lucutan pijar akan berpengaruh pada peningkatan jumlah atom-atom gas di dalam tabung plasma. Semakin banyak atom karbon maka tumbukan akan semakin sering terjadi, hal ini menyebabkan energi atom akan lebih cepat habis sehingga untuk dapat memicu proses ionisasi diperlukan energi listrik yang lebih besar. Oleh karena itu, diperlukan nilai tegangan yang lebih besar untuk dapat terjadi discharge. Berdasarkan Tabel 1 dapat dilihat bahwa semakin besar tegangan yang diperlukan untuk membentuk plasma, maka akan semakin besar pula nilai arus yang dihasilkan. Hubungan tegangan dan arus dapat dilihat pada Gambar 4 .

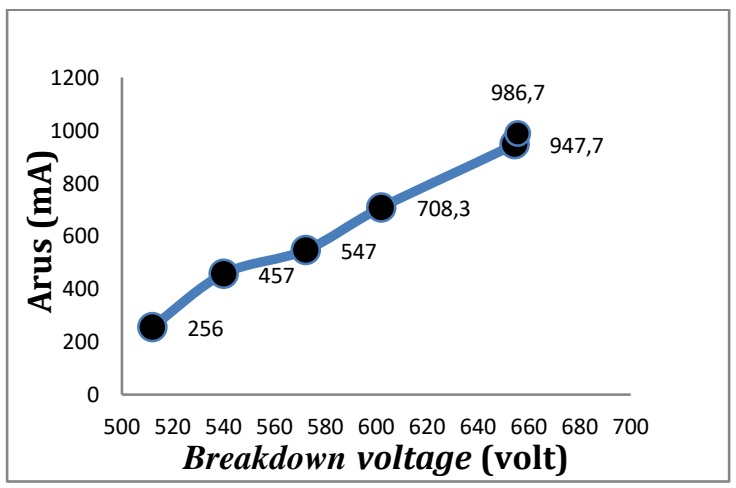

Gambar 4. Hubungan tegangan dan arus

Hasil pengamatan menunjukkan bahwa peningkatan nilai breakdown voltage akan sebanding dengan peningkatan nilai arus. Hal ini disebabkan karena pemberian tegangan berfungsi untuk mempercepat gerak ion atau elektron ke target. Semakin cepat gerak ion atau elektron, akan semakin sering terjadi tumbukan. Semakin sering terjadi tumbukan maka proses ionisasi berantai akan semakin sering terjadi. Proses ionisasi berantai akan menyebabkan jumlah elektron dan ion bertambah sehingga nilai arus juga semakin bertambah.

\subsection{Pembentukan Lapisan Tipis}

Proses ini berawal dari disosiasi atom karbon sampai proses ionisasi sehingga terbentuk plasma yang dapat dituliskan sebagai berikut

$$
\begin{aligned}
& \mathrm{e}+\mathrm{CH}_{4} \rightarrow \mathrm{CH}_{3}^{2+}+2^{\mathrm{e}-} \\
& \mathrm{CH}_{3}{ }^{2+}+2^{\mathrm{e}-} \rightarrow \mathrm{CH}_{2}^{3+}+3^{\mathrm{e}-} \\
& \mathrm{CH}_{2}^{3+}+3^{\mathrm{e}-} \rightarrow \mathrm{CH}^{4+}+4^{\mathrm{e}-} \\
& \mathrm{CH}^{4+}+4^{\mathrm{e}-} \rightarrow \mathrm{C}^{5+}+5^{\mathrm{e}-}
\end{aligned}
$$

Dalam proses pembentukan lapisan tipis atau proses deposisi dengan cara target ditembak dengan ion karbon yang bergerak cepat dalam suatu sistem vakum. Karena proses tersebut, atom-atom permukaan stainless steel (memiliki unsur utama $\mathrm{Fe}$ ) terlepas dan terpercik ke segala arah dan sebagian besar menuju target.

Atom-atom baja (Fe) yang terpercik akan bertemu dengan atom $\mathrm{C}$ yang terdisosiasi sehingga membentuk senyawa FeC. Karena memiliki energi yang cukup, senyawa $\mathrm{FeC}$ akan menumbuk ke permukaan target dan mendesak atom-atom permukaan target menuju tempat interstisi atau mengisi kekosongan pada target dan sebagian akan menempel pada permukaan. Setelah kekosongan sudah terpenuhi, atomatom yang datang berikutnya akan menumbuk atom-atom yang datang terlebih dahulu yang telah membentuk lapisan tipis. Kemudian akan menumpuk senyawa FeC pada permukaan dan akan terjadi difusi serta membentuk lapisan tipis yang halus.

Reaksi besi dan karbon akan membentuk fasa baru yaitu FeC yang mempunyai sifat sangat keras. Senyawa yang terbentuk adalah FeCFe3C. Perbedaan senyawa ini adalah pada persentase komposisi atom karbon yang membentuk senyawa karbida besi ( $\mathrm{Fe}-\mathrm{Fe}_{3} \mathrm{C}$ ). Gambar permukaan SS 316L sebelum dan sesudah di-surface treatment dapat dilihat pada Tabel 2 .

Tabel 2. Permukaan SS 316L sebelum dan sesudah pembentukan lapisan tipis

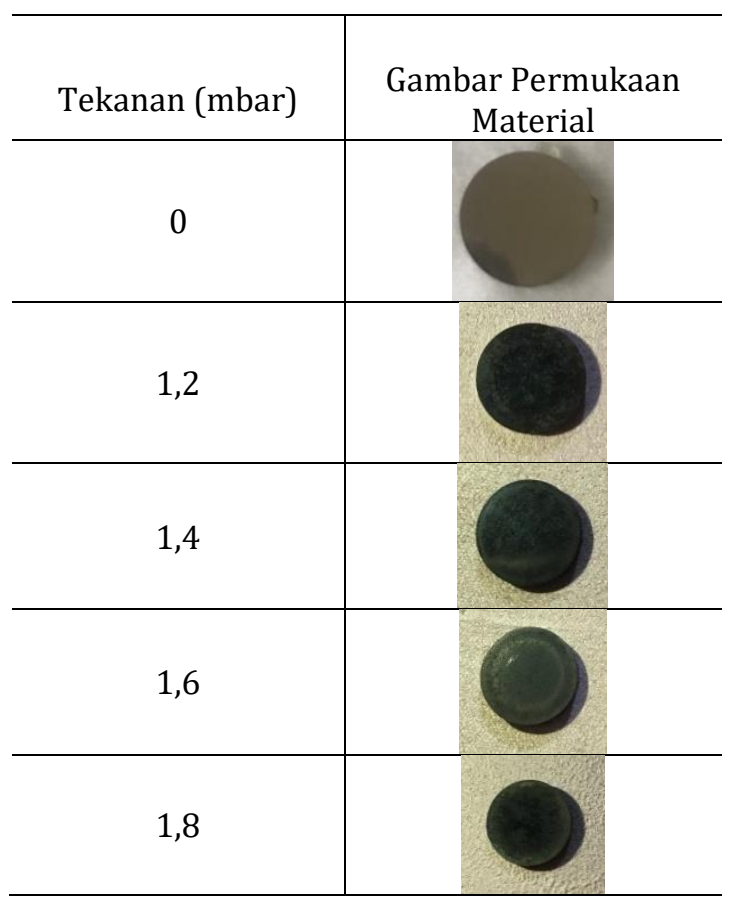


Pada Tabel 2 dapat dilihat terjadi perubahan penampilan pada sampel sebelum diberi perlakuan dan sesudah diberi perlakuan yaitu terjadi perubahan warna menjadi hitam, hal ini terjadi karena sifat umum dari unsur karbon yaitu berpenampilan hitam (grafit).

\subsection{Uji Kekerasan}

Pengujian kekerasan dilakukan pada permukaan SS 316L tanpa karburasi plasma (raw material) maupun SS 316L yang telah dikarburasi plasma selama 4 jam dengan suhu $400^{\circ} \mathrm{C}$. Pemberian beban terhadap material (indentasi) dilakukan dengan menggunakan beban indentor $10 \mathrm{~g}$ dan waktu indentasi selama 10 detik pada 5 titik yang berbeda dengan variasi tekanan 1,$2 ; 1,4 ; 1,6$; dan 1,8 mbar. Hasil pengujian kekerasan ditunjukkan pada Tabel 3 .

Tabel 3. Nilai Kekerasan Vickers (VHN) permukaan SS $316 \mathrm{~L}$ hasil proses plasma karburasi pada suhu $400{ }^{\circ} \mathrm{C}$ dan waktu 4 jam dengan variasi tekanan.

\begin{tabular}{ccccccc}
\hline \multirow{2}{*}{$\begin{array}{c}\text { Tekanan } \\
\text { (mbar) }\end{array}$} & & \multicolumn{7}{c}{ Kekerasan (VHN) } & Rata- \\
& 1 & 2 & 3 & 4 & 5 & Rata \\
& VHN) \\
\hline 0 & 112,7 & 107,4 & 107,5 & 103,5 & 116,1 & 109,44 \\
1,2 & 141,9 & 129,5 & 124 & 132,8 & 130,4 & 155,66 \\
1,4 & 179,2 & 178,5 & 177,3 & 186,1 & 176,9 & 179,6 \\
1,6 & 226 & 213,3 & 226,8 & 227,6 & 249,3 & 228,6 \\
1,8 & 180,7 & 192,4 & 177,4 & 180,4 & 180,8 & 182,34 \\
\hline
\end{tabular}

Dari data tersebut diketahui bahwa rata-rata kekerasan awal SS 316 L (raw material) ditunjukkan pada titik 0 adalah 109,44 VHN. Dari variasi tekanan dapat dilihat bahwa pada tekanan 1,6 mbar menunjukkan nilai kekerasan optimum dengan rata-rata kekerasan 228,6 VHN dari nilai kekerasan awal. Pada variasi tekanan 1,2 mbar diperoleh nilai rata-rata kekerasan 155,66 VHN dari nilai kekerasan awal. Pada variasi tekanan 1,4 mbar dan 1,8 mbar diperoleh nilai kekerasan rata-rata sebesar 179,6 VHN dan 182,34 VHN. Grafik peningkatan kekerasan dapat dilihat pada Gambar 5.

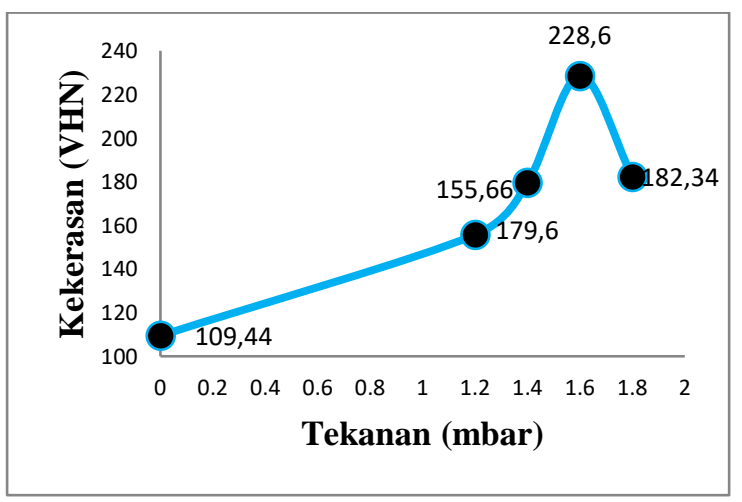

Gambar 5. Grafik peningkatan kekerasan pada permukaan SS $316 \mathrm{~L}$ pada suhu $400^{\circ} \mathrm{C}$ dan waktu 4 jam dengan variasi tekanan

Gambar 5 memperlihatkan bahwa setiap tekanan mengalami peningkatan kekerasan dari kekerasan awal. Sehingga persen peningkatan kekerasan dapat dilihat pada Tabel 4 .

Tabel 4. Persentase peningkatan kekerasan permukaan SS $316 \mathrm{~L}$ hasil perlakuan karburasi plasma dengan suhu $400{ }^{\circ} \mathrm{C}$ dan waktu 4 jam dengan variasi tekanan terhadap raw material.

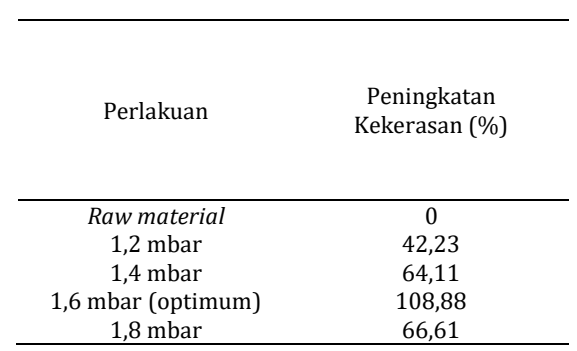

Dapat dilihat pada Tabel 4 bahwa pada tekanan 1,2; 1,4; 1,6 dan 1,8 mbar diperoleh peningkatan kekerasan berturut-turut sebesar 42,23\%; 64,11\%; 108,88\% dan 66,61\%.

Hasil menunjukkan bahwa makin besar tekanan yang diberikan pada proses karburasi, maka akan semakin tinggi kekerasan yang dihasilkan dan mencapai puncak pada tekanan 1,6 mbar. Jika tekanan ditambah ternyata kekerasan menurun. Penurunan kekerasan terjadi karena sampel telah sampai pada fase jenuh. Fase jenuh dapat diartikan sebagai fase ketika atom-atom yang terdeposisi pada permukaan sampel telah mencapai batas maksimum. Pada fase ini atom-atom karbon yang terdeposisi ke dalam permukaan substrat sudah tidak membentuk ikatan karbida besi, melainkan hanya tumpukan atom-atom karbon. Penumpukkan atom-atom karbon akan menyebabkan atom karbon menempel pada permukaan sampel. Hal ini menyebabkan ukuran butir (grain size) membesar (growth). Menurut hukum Hell Petch, bahwa kekuatan bahan itu berbanding terbalik dengan ukuran butir. Dengan demikian, makin besar ukuran butir maka kekerasannya akan menurun [8].

\section{Kesimpulan}

Berdasarkan hasil dan analisis yang telah dilakukan, maka dapat ditarik kesimpulan bahwa pada tekanan gas sebesar 1,$0 ; 1,2 ; 1,4$; 1,6; 1,8; dan 2,0 mbar, diperoleh nilai breakdown voltage sebesar 512; 540; 572,3; 602; 654,3 dan 655,7 volt. Pada nilai tegangan tersebut, arus yang diperoleh sebesar 256; 457; 
547; 708,3; 947,7dan 986,7 mA. Sedangkan kondisi optimum dari variasi tekanan gas metana $\left(\mathrm{CH}_{4}\right)$ untuk meningkatkan kekerasan permukaan SS 316L dengan jarak antar elektroda, suhu, dan waktu nitridasi dibuat konstan terjadi pada tekanan gas sebesar 1,6 mbar, dengan nilai kekerasan 228,6 VHN atau meningkat sebanyak 108,88\%.

\section{Pengakuan}

Penulis mengucapkan terima kasih kepada PSTA BATAN Yogyakarta yang telah memberi izin untuk melaksanakan penelitian.

\section{Daftar Pustaka}

[1] Purwanto, Malau, V. \& Sujitno, T., Pemanfaatan teknik plasma dalam proses nitridasi pada baja paduan DIN 42CrMo4, Yogyakarta, PSTA BATAN, 2003.

[2] Hardi, T., Texture Analysis using The Neutron Diffraction Method on The Non Standardized Austenic Steel Process by Machining, Annealing and Rolling. Makara J Technologi, 19-23, 2016.

[3] Smallman, R.E. \& Bishop, R.J., Metalurgi Fisik Modern dan Rekayasa Material. Jakarta: Penerbit Erlangga, 2010.

[4] Rukmana, V.H., Penumbuhan Lapisan Tipis Titanium Nitrida (TiN) pada Permukaan SS 316L dengan Teknik Sputering, Yogyakarta: STTN-BATAN, 2017.

[5] Suprapto, Sujitno, T. \& Mudjijana, Pengerasan permukaan baja ST 42 dengan teknik nitridasi ion. Yogyakarta, Puslitbang Teknologi Maju-BATAN, 2008.

[6] Sujitno, T., Pelatihan Teknologi Akselerator dan Aplikasinya, Yogyakarta: PTAPB BATAN, 2003.

[7] Ekaputra, Pengaruh Pelapisan Permukaan Baja Poros dengan Metode Plasma Carburizing Menggunakan Gas CH4 dan Helium, Yogyakarta: STTN BATAN, 2016.

[8] Suprapto, I., Pengembangan Teknologi Plasma untuk Nitridasi. KPTF PSTA-BATAN, Yogyakarta: Pustaka Belajar dan BATAN, 2018. 